\title{
Financial service firms' entry-mode choice and cultural diversity: Spanish companies in Latin America
}

\author{
María José Álavarez-Gil \\ Universidad Carlos III de Madrid, Madrid, Spain \\ Clara Cardone-Riportella \\ Universidad Carlos III de Madrid, Madrid, Spain \\ Nora Lado-Cousté \\ Universidad Carlos III de Madrid, Madrid, Spain \\ Margarita Samartín-Sáenz \\ Universidad Carlos III de Madrid, Madrid, Spain
}

\section{Keywords}

Financial services,

Newly industrializing economies, Internationalization, Latin America

\section{Abstract}

Emerging markets in newly industrialised countries have caught the attention of managers of manufacturing companies facing heavy domestic and global pressure. Key barriers to the effective management of international manufacturing operations need to be identified. The same applies to the management of international service operations. The share of services in international trade, the amount of foreign direct investments made and the number of multinational service sector enterprises has been increasing rapidly in the last two decades. Existing studies on service internationalisation apply a fairly broad theoretical base. This paper contributes by examining the internationalisation behaviour of Spanish financial service sector companies in Latin America to find out if general internationalisation patterns are applicable or if the manufacturing sector influences their internationalisation behaviour.
Introduction

Activities linked to service-sector companies, as well as foreign direct investment made by service-sector companies (from now on FDI) have significantly grown since the late 1980s[1]. In spite of the increasing importance of this sector, the theoretical literature that revises the internationalisation process of the firm, has mostly focused on the manufacturing sector (Andersen, 1993), so that analytical frameworks used to guide multinational managerial decision-making have been based upon evidence collected from the manufacturing sector (Brush et al., 1999). However, the differences between the inherent characteristics of services vs manufacturing goods suggest that the key challenges facing service multinational companies, as well as the main principles which guide their strategic management, may be quite different from those related to the manufacturing multinational enterprises as suggested by Campbell and Verbeke (1994).

In the context of business services, the knowledge of which industries are most oriented to international markets and the ways in which they enter and develop them is very scarce as yet. Such research as exists has tended to focus either upon manufacturing firms or upon very large English-speaking global service organizations to the neglect of the vast majority of business service firms. Our study is an exploratory study of internationalisation by Spanish financial services enterprises, that follows the outlines of previous papers by Engwall and Wallenstal (1988) and Hellman (1994), who studied the internationalisation of Nordic financial service companies all over the world. In Spain, FDI accounted for 38 per cent of GNP in 1980, and this figure increased to 60 per cent in 1990, which indicates that service operations management is becoming a very challenging topic in this country, the Latin American market being the most important destination of the Spanish FDI.

The exposure of Spanish firms to Latin America may be explained by two factors: on one side, the consolidation of the Spanish economy after its integration in the EU, i.e. an internalisation factor, and on the other side, the deregulation and liberalisation of the Latin American market, i.e. an internationalisation factor. The restructuring of the LA financial markets and the challenges that it might represent for the Spanish financial companies mean that there is a greater need for managers in such firms to think strategically and develop effective competitive strategies to create and sustain competitive advantages in such a geographical area. Besides, the identification and examination of the significant location characteristics provides investors, development agencies and researchers with a better understanding of foreign investment practices among service companies. So far, a greater understanding of the dynamics of the internationalization process of Spanish financial service companies in LA is required, as it may be affected, among other factors, by:

- regulatory changes;

- the influence of home market conditions upon the timing of the decisions to internationalize; and

- the international behavior and requirements of private and public sector clients.

Thus, the aim of this paper is to explore the penetration in the LA markets by Spanish financial service companies, banks and 
María José Álavarez Gil, Clara Cardone Riportella, Nora Lado Cousté and Margarita Samartín Sáenz Financial service firms' entry-mode choice and cultural diversity: Spanish companies in insurance companies particularly, by focusing on five enterprises' historical process of internationalisation. The analysis is based on rank correlation between the internationalisation patterns of each company and the relevant indicators of this phenomenon for the period 1985-1996. Such relevant indicators are:

- total amount of Spanish net investments (no portfolio investments included);

- total amount of Spanish exports of manufactured products;

- index of deregulation and liberalisation of financial markets;

- leading international banking countries in Latin America, in terms of foreign banking activities; and

- leading international insurance countries, in terms of insurance premiums.

The rest of this article takes the following format. The following section presents the theoretical framework related to the internationalisation of the firm and the main research questions that will be discussed in this work. In the third section the entry modes of four Spanish banks and one insurance company in Latin America are shown. The data and methodology used in the analysis are described in the fourth. The empirical study is presented in the fifth section. Finally, a concluding section brings the article together and notes some implications, such as for management and researchers.

The internationalisation of the firm in the service sector

The internationalisation process experienced by manufacturing firms led researchers to provide analytical frameworks in order to explain the internationalisation behaviour of the above mentioned firms[2]. In a similar way, the increasing growth of FDI made by service firms is motivating academics to explore the internationalisation pattern of the service sector, and to see whether this international market entry, can be differentiated or not, from the one followed by manufacturing firms.

Regarding service sector companies, Dunning (1989) concludes that the major reasons for their internationalisation process are the following ones:

- global or regional strategic reasons;

- the product's characteristics;

- competitors' behaviour; and

- politics or regulation of the host country.
Erramilli (1992) examines the main internal and external environmental factors that might influence entry mode in international markets. The major external factors would be:

- restrictions on foreign investment;

- country-risk (of the host country);

- market size; or

- finding no partnerships in the host country.

Examples of internal factors are:

- the firm's wish to expand abroad;

- the need of human or material resources to carry out the process; and

- political control on international operations.

Li and Guisinger (1992) have suggested the following main reasons as to why firms expand:

- market size;

- cultural distance and regulation;

- comparative advantages;

- market characteristics; and

- firm's size and growth opportunities.

Results from their article show that FDI of service sector companies is positively related to market size and liberalisation.

Empirical research on business practice has consistently highlighted market similarity as the major determinant of international market entry, i.e. similarity of the foreign market to the firm's home market (Erramilli, 1991). Uppsala School researchers argue that exporting begins with "psychologically close" countries and extends incrementally to "psychologically distant" ones as the firms gain experience (Buckley et al., 1992; Johanson and Vahlne, 1977; Wiedershein et al., 1978).

Studies dealing with the service sector (see inter alia Campbell and Verbeke, 1994;

Erramilli and Rao, 1993; Mathe and Perras, 1994; Sarathy, 1994a, b; O'Farrell, et al., 1996; 1998), have focused on the following specific services:

- hotels (Dunning and McQueen, 1981);

- advertising agencies (Terpstra and Yu, 1988); and

- banking (Grubel, 1977; Gray and Gray, 1981; Giddy, 1986; Aliber, 1984; Cho, 1986; Nigh et al., 1986; Williams, 1997, inter alia).

In the case of the last two specific services, there seems to be evidence that supports the idea that their internationalisation strategy is driven by "customer following" considerations. Nevertheless, their strategies may differ depending on the development of 
María José Álavarez Gil, Clara Cardone Riportella, Nora Lado Cousté and Margarita Samartín Sáenz Financial service firms' entry-mode choice and cultural diversity: Spanish companies in new technologies such as electronic commerce (Winsted and Paterson, 1998).

It could be said that although there seems to be no general theory that explains the internationalisation process of the service sector, research in this field has given different explanations to this phenomenon.

\section{Entry modes}

Recent research suggests that the internationalisation pattern of service firms is explained by one of the two phenomena referred to as "customer following" or "market seekers" (Erramili and Rao, 1990; Marjhgard and Sharma, 1998; Gronroos, 1999) and which are explained below. In particular Gronroos (1999), adds a new mode of entry: electronic "marketing mode", which is the result of technological development (Internet and satelite, and digital television).

As mentioned above, the general theory on the internationalisation of the firm has been applied to explain a more recent phenomenon, the internationalisation of service companies. Our paper resembles previous studies (Erramilli, 1990; 1992; Erramilli and Rao, 1990; 1993; Hellman, 1994) in that the manufacturing sector is considered as a reference to explain how banking and insurance companies make their decisions concerning entry-choice mode and allocation of resources.

In most cases, the internationalisation process of banks and insurance firms seems to fit the above mentioned phenomena of "customer following", or "markets seekers" (see Sarathy, 1994a, b; Hellman, 1994). Andersen (1993) and Johanson and Mattson (1988) have pointed out that this behaviour coincides with marketing strategies, where the internationalisation can be seen as a way of maintaining a relationship with original clients which are abroad now, and also as a way to search for new clients.

According to what is suggested by the literature, the expansion of Spanish banks to Latin America may be due to several factors:

- short cultural "distance" between those countries and Spain[3,4];

- market structure;

- low degree of banking activity;

- economic stability;

- financial sector liberalisation; and

- strategic importance of this region in order to establish agreements with other European and American banks[5].

At the same time, banking activity in Spain has undergone a tremendous change. Entry into the European Union (EU), and later on, the European Monetary Union (EMU) implied:
- an increase in competition;

- a decrease in profitability; and

- the liberalisation of the banking sector.

Under this framework, financial institutions have reacted combining two types of strategies: specialisation strategies and growth strategies, so that a process of mergers and alliances has taken place among financial institutions in order to acquire enough size to compete at the European level[6]. Also, some financial institutions mostly the biggest banks have followed an active internationalisation strategy, in order to increase their exposure in those international markets that offer new investment opportunities.

These firms going international are faced with far more ambiguity, both internally and externally, than are their domestic counterparts. The ambiguity that is partly due to nuances of language and culture that may be difficult to identify, let alone understand, and to national social and cultural biases and norms, is somehow softened by the fact that the cultural distance is very short and a common language is spoken. Managers are not helped by the fact that the breadth and scope of markets make objective analysis and consensus building difficult.

It should be pointed out that during the late 1980s and early 1990s most LA countries had lifted restrictions on foreign investment, making them more interesting for foreign investors. Table I illustrates the main changes that have taken place. They can be summarised as:

- equal treatment for domestic and foreign investment;

- removal of controls for the repatriation of capital and profits;

- authorisation to carry on FDI in protected sectors (such as banking); and

- establishment of private and public agencies to promote FDI in the region.

As mentioned before, the dominant features in the internationalisation of service companies is what may be called "customer following". These firms enter foreign markets following their local customers, i.e. manufacturing companies, which had already entered those markets. A particular case can also be considered, wherein the domestic market is organised as an oligopoly: the internationalisation process might be a reaction to the strategy followed by the main local competitor. This phenomenon is known as "follow the leader" (Li and Guisinger, 1992; Engwall and Wallenstal, 1988). 
María José Álavarez Gil, Clara Cardone Riportella, Nora Lado Cousté and Margarita Samartín Sáenz Financial service firms' entry-mode choice and cultural diversity: Spanish companies in
On the other hand, it has been observed that certain service companies are known as "market seekers". In this sense, once these firms have gained a high enough market share in their domestic market which becomes hard to increase, they search for new markets. This is probably the case for financial service companies (Hellman, 1994), particularly banks and insurance firms. Banks tend to concentrate in major international centres, in order to gain access to financial capitals while, at the same time, insurance companies tend to concentrate in the same markets in order to be close to their competitors and to gather access to the reinsurance markets.

Because previous studies considering the internationalisation process of either banks or insurance companies have offered controversial explanations of the issues dominating that process, we have formulated the following research questions:

- Has the internationalisation of Spanish banks in LA been dominated by customer following considerations or, alternatively, has it been dominated by market seeking considerations?

- Has the internationalisation of the Spanish most relevant insurance company in LA been dominated by customer following considerations or, alternatively, has it been dominated by market seeking considerations?

\section{Entry modes of Spanish banks and insurance company in LA}

In order to examine the internationalisation process of financial institutions, four major Spanish banks and one insurance company will be considered. The banks to be considered are Banco Santander (BS), Banco Central Hispano (BCH), Argentaria (BEX) and Banco Bilbao Vizcaya (BBV)[7]. These banks have been present in LA for nearly three decades. The insurance company to be considered is MAPFRE. This insurance company has a significant presence in the Latin American market and is the only one with 100 per cent Spanish capital.

We shall discuss the different steps as taken by these banks and the insurance company as analysed in the following sections.

\section{Banco de Santander (BS) Latin American entry modes}

The BS's[8] internationalisation process in Latin America was carried out in two well-defined stages:

$\overline{\text { Table } 1}$

Regulation of FDI in the different Latin American countries

\begin{tabular}{|c|c|c|c|c|c|}
\hline Entry (a) & \multicolumn{2}{|c|}{$\begin{array}{c}1988 \\
\text { Exit (b), repatriation of: }\end{array}$} & Entry (a) & \multicolumn{2}{|c|}{$\begin{array}{c}1995 \\
\text { Exit (b), repatriation of: }\end{array}$} \\
\hline Free entry & & & Free entry & & \\
\hline No country & & & $\begin{array}{l}\text { Argentina, Ecuador } \\
\text { Brazil, Mexico } \\
\text { Costa Rica, Peru }\end{array}$ & Free & Free \\
\hline Relatively free & & & Relatively free & & \\
\hline Argentina & Restricted & After three years & Chile & Free & After one year \\
\hline Chile & Free & After five years & Venezuela & Some restrictions & Some restrictions \\
\hline Costa Rica & Some restrictions & Some restrictions & & & \\
\hline Venezuela & Some restrictions & Some restrictions & & & \\
\hline \multicolumn{6}{|l|}{ Special classes } \\
\hline Mexico & Free & Free & & & \\
\hline Authorised funds & & & Authorised funds & & \\
\hline Brazil & Free & Some restrictions & Colombia & Free & Free \\
\hline \multicolumn{6}{|l|}{ Closed } \\
\hline Colombia & Some restrictions & Free & & & \\
\hline Peru & Restricted & Restricted & & & \\
\hline
\end{tabular}

Notes: (a) Entry: free entry: no restrictions at all; relatively free: some restrictions to assure repatriation rights; special classes: FDI restricted to special classes; authorised funds: only approved foreign investors; closed: FDI very restricted, only for non-residents;

(b) Exit: repatriation of income: dividends, interest, income; repatriation of capital: initial capital invested; free: repatriation done frequently; some restrictions: requires permission of authorities 
María José Álavarez Gil, Clara Cardone Riportella, Nora Lado Cousté and Margarita Samartín Sáenz Financial service firms' entry-mode choice and cultural diversity: Spanish companies in
1 A first stage prior to the nineties where it only set up representation offices in four countries whilst at once signing agreements with banks in Puerto Rico.

2 A partial and total purchase process of banks not having a significant market share commenced in the 1990s.

Basically, the strategy followed involved the following points:

- The taking of majority holdings when the local partner allowed. Partial purchases range from 37.06 per cent to 98 per cent and full purchases.

- Implementing its commercial name. The confidence inspired by the corporate image allows for banking models previously applied with success in local markets to be used, e.g. marketing of the same financial products as those marketed in Spain in the past.

- The bank reserved management of the entity partially or totally acquired.

- Universal banking practice (commercial, corporate, private banking, capital market, etc.).

$\mathrm{BS}$ is present in nine of the region's countries, the same into which BBV its main competitor subsequently entered, except for Panama where it is not currently present.

\section{Banco Bilbao Vizcaya (BBV) Latin America} entry modes

Likewise, two stages can be seen in BBV's internationalisation in LA in the analysis, except for investments made in Panama (1983) and Puerto Rico (1982) for the reasons we shall discuss later:

1 The first, developed between 1994 and 1998, consisted in the BBV group's positioning in emerging markets, for which it commenced a disinvestments process in mature markets and an investment process in LA. During this stage, the bases for the internationalisation process were as follows:

- Control of the local entity, making the minimum of investment partial purchases ranged from 3.9 per cent to 71.75 per cent and total purchases. Selection of leading entities in investment target countries, which could provide knowledge of the market and institutional models.

- Providing human resources, although few, to back local managers.

- Implementing the commercial name. In the first stage, the strategy used was to keep the name of the local partners as a way of using their experience and recognition of their own markets.

- Universal banking practice.

2 The second stage in the internationalisation process (initiated in 1998) consists in converting the group into a franchise, which brings with it the creation of a multidomestic global group combining local advantage with global advantage. The global advantage held by the purchasing group is the possession of an overall view of risks and opportunities apart from possessing highly developed technological levels.

$\mathrm{BBV}$ is present in ten LA countries. In June, 1998, the purchase of 55 per cent of the Chilean Banco Hipotecario de Fomento was made. BBV was pending entry into this country, together with Brazil, where its main competitor is BS.

\section{Banco Central-Hispano (BCH) Latin American entry modes}

$\mathrm{BCH}$ 's internationalisation process may also be described in two stages:

1 In the period prior to $1990, \mathrm{BCH}$ only set up representation offices although during the second stage, this was a path to internationalisation applied to countries like, for example, Uruguay.

2 During the 1990s, the predominant strategy was to make partial acquirements ranging from 0.03 per cent to 90.0 per cent. Banco Central-Hispano's investment strategy may be summed up basically as follows:

- Entry into the Latin American market effected through a local bank. In 1993, BCH had a branch in Chile which it integrated into Banco O'Higgins (local), thus giving rise to the holding company, O'Higgins Central-Hispano (OHCH). In Argentina, Uruguay, Paraguay and Peru, it operates through this O'Higgins Central-Hispano holding company. In Mexico, it has an interest of only 10 per cent of Banco Internacional BITAL.

- Search for business opportunities in potential growth entities.

- Taking advantage of existing office network.

- Non intervention in management. This is the point differentiating it from the two banks analysed above. 
María José Álavarez Gil, Clara Cardone Riportella, Nora Lado Cousté and Margarita Samartín Sáenz Financial service firms' entry-mode choice and cultural diversity: Spanish companies in

\section{Argentaria (BEX) Latin American entry} modes

Banco Exterior forms part of the largest public bank holding company in Spain, Argentaria. BEX entered LA in the past to finance foreign trade transactions between the region's countries and Spain service banking. In the 1980s, during the debt crisis, it commenced a disinvestment process.

Argentaria (BEX) America exists today. This bank unified its subsidiaries in Argentina, Brazil, Chile and Paraguay. It also holds 19.9 per cent of the capital of Extebandes in Bolivia, Colombia, Ecuador, Peru and Venezuela.

\section{MAPFRE Latin American entry modes} MAPFRE's international strategy in Latin America was a sequential set of strategic choices. Re-insurance from the home market was the first choice and it was a successful strategy, so much that by the end of the 1980s MAPFRE had already started operations in direct insurance and reinsurance in Argentina, Brazil, Colombia, Paraguay, Uruguay and Venezuela. For example, in Chile the Euroamérica insurance companies (life and non-life) and the reinsurance firm Caja Reaseguradora, reinforced operations in Argentina, were Amandria (later on MAPFRE Aconcagua) was already present in direct insurance, with the opening of a reinsurance representative office.

During the 1990s MAPFRE began operations in travel assistance directly from several countries in Latin America (Argentina, Brazil, Chile, Colombia, Dominican Republic, Ecuador, Mexico, Peru and Venezuela) and started operations in direct insurance in Mexico, Puerto Rico and Venezuela, reinforcing local subsidiaries with further mergers (Paraguay) and investments in real estate and local facilities (ITSEMAP, CESVIMAP, etc.).

Over its corporate history, MAPFRE has developed competitive advantage based on intangibles such as know-how, reputation for high quality in services and corporate culture, with strong differentiating features such as values considered common among MAPFRE personnel, i.e. solvency, trustworthiness and loyalty. This conservatism has not prevented MAPFRE from having a considerable marketing dynamism based on quick internal information, which allows emulation among managers, and on considerable extent resultbased incentive systems.

In 1996, the MAPFRE system had a turnover of more than 600,000 million pesetas ( $\$ 4,800$ million), with around 77 per cent of income in insurance, 17 per cent in reinsurance and 6 per cent in other services (banking, assistance, real state, etc.). Of this income around one third comes from abroad (mainly Latin America). Table II presents the entry years of MAPFRE in different Latin American countries.

\section{Data and methodology}

The study period will be from 1985 to 1996 , given that those years are the most representative ones as they concern the entries by these institutions in the various countries. In order to analyse entry into the different markets, the first year of contact or establishment of the institution has been taken into account. In previous decades, financial institutions had entered the market by first establishing a representative office, which was later turned into a subsidiary, or by merging partially or completely with other local institutions.

The data were obtained from the annual reports of financial institutions, national newspapers and articles published in specialised journals. The analysis is carried out by rank correlation between the internationalisation pattern of each financial service company, given the year of first entry (either by representative office, subsidiary or merger) and the relevant indicators of customer following and market seeking approaches. The Kendall's tau-b correlation coefficient is applied in the analysis.

\section{Customer following approach}

In order to measure whether or not financial service companies enter foreign markets in order to follow their local clients, i.e. manufacturing companies, three indicators will be used:

1 The total amount of Spanish net investments for the specified period, i.e. FDI minus portfolio investments (data source: official statistics provided by "Dirección General de Transacciones Exteriores").

2 The total amount of Spanish exports of manufacturing goods for the specified period (data source: official statistics provided by "Instituto de Comercio Exterior").

3 Index of de-regulation and liberalisation in LA, which summarises the restrictions on FDI that exist in the different LA markets (data source: each country's legislation and World Investment Report, 1996)[9]. 
María José Álavarez Gil, Clara Cardone Riportella, Nora Lado Cousté and Margarita Samartín Sáenz Financial service firms' entry-mode choice and cultural diversity: Spanish companies in
The index has been defined taking into account the existing legislation on FDI in two different years, 1988 and 1995. There is also a distinction between restriction on entry and on exit (repatriation of income and capital).

On the entry side regulation, the following levels have been considered:

- free entry or no restrictions at all;

- relatively free entry: some registration procedures to ensure repatriation rights;

- special classes: investment restricted to certain classes designated for foreign investors;

- authorised investors only: only approved foreign investors; and

- closed: closed or access severely restricted.

Similarly, on the exit side regulation, the following levels are taken into account:

- free: repatriation done routinely; and

- some restrictions: requires some registration with or permission of Central Bank, Ministry of Finance or an Office of Exchange Controls that may restrict the timing of exchange release.

(The above levels have been weighted as follows: entry: 10, 7.5, 5, 2.5 and 0 respectively. exit: 10,5 and 0 respectively.)

\section{Market seekers approach}

The market-seeking aspect has been measured by comparing the internationalisation patterns of the banks and the insurance companies to the indicators proposed by Hellman (1994), i.e.

- Leading international banking countries in terms of foreign banking activities, according to data obtained from the Bank for International Settlements (Table I: consolidated international claims of BIS reporting banks on individual countries; November 1998).
- Leading international insurance countries in terms of average amount of insurance premiums issued per country, according to data obtained from "Actualidad Aseguradora".

\section{Results}

Table III presents the ranking of the LA countries, in terms of the indicators defined above[10]. In some cases, there has been a limitation with the data available for the various indicators, in particular, for the one referring to FDI regulation (both entry and exit regulation).

Table IV illustrates the correlation analysis among the various indicators. It can be observed that there is always a significant positive correlation except for the case of FDI regulation. This may be due to the limitation in the availability of the data, as mentioned before.

Finally, Table V shows the rank correlation, measured with the $t a u-b$ Kendall coefficient, between the first year of entry for each bank and insurance company in Latin America and the various indicators for customer following and market seeking.

Table $\mathrm{V}$ also shows the rank correlation among internationalisation patterns of competitive firms. It can be observed that there is a high correlation between the internationalisation patterns of two of the studied banks, on one hand, and the insurance companies, on the other. These results provide empirical support for the existence of a phenomenon whereby companies are following the path designed or initiated by their most relevant domestic competitor, i.e. we are in the presence of a "following the leader" strategy.

\section{Table II}

The MAPFRE system in Latin America

\begin{tabular}{llll}
\hline $\begin{array}{l}\text { Unit } \\
\text { Activity }\end{array}$ & $\begin{array}{l}\text { MAPFRE Internacional } \\
\text { Direct Insurance }\end{array}$ & $\begin{array}{l}\text { MAPFRE Re } \\
\text { Reinsurance }\end{array}$ & $\begin{array}{l}\text { MAPFRE Asistencia } \\
\text { Travel assistance }\end{array}$ \\
\hline Activity based in: & MAPFRE Aconcagua (Argentina) & CAJA Reaseguradora (Chile) & Ibero Asistencia (Argentina) \\
(subsidiaries or & Vera Cruz Seguradora (Brazil) & Reaseguradora Hemisferica (Colombia) & Brasil Asistencia (Brazil) \\
participations in & MAPFRE Seguros Generales de & Representative offices in: & Andi Asistencia (Colombia) \\
local companies) & Colombia (Colombia) & Buenos Aires (Argentina) & Caribe Asistencia (Dominican Republic) \\
& Euroamérica Seguros Generales (Chile) & Caracas (Venezuela) & Ecuasistencia (Ecuador) \\
& Seguros Teyepac (Mexico) & México (Mexico) & Mexico Asistencia \\
& MAPFRE Paraguay (Paraguay) & & (Mexico) \\
& Seguros el Sol Nacional (Peru) & & Peru Asistencia (Peru) \\
& Praico (Puerto Rico) & & Federal Asistencia \\
& MAPFRE Uruguay (Uruguay) & & (Puerto Rico) \\
& MAPFRE Venezuela (Venezuela) & & Veneasistencia (Venezuela)
\end{tabular}


María José Álavarez Gil, Clara Cardone Riportella, Nora Lado Cousté and Margarita Samartín Sáenz Financial service firms' entry-mode choice and cultural diversity: Spanish companies in
The internationalisation process of all entities (banks and insurer) seems to be influenced at the same time by "market seeking" and "customer following" considerations. Moreover, the pre-eminence of either client following or market seeking may have changed over the time, but our analysis is unable to detect these changes in the internationalisation behaviour of the firms.

Based on our results, the internationalisation process of BS can be described as being dominated by customer

\section{Table III}

Ranking of the LA countries according to selected indicators

\begin{tabular}{lccccc}
\hline Countries & FDI & Exports & Deregulation & International financial centres & Insurance premiums \\
\hline Argentina & 2 & 2 & 3 & 3 & 3 \\
Bolivia & 13 & 13 & N/A & 13 & 14 \\
Brazil & 6 & 3 & 4 & 1 & 1 \\
Chile & 7 & 4 & 4 & 4 & 5 \\
Colombia & 9 & 6 & 8 & 5 & 6 \\
Ecuador & 8 & 10 & N/A & 9 & 10 \\
Guatemala & $14+$ & $15+$ & N/A & 11 & 13 \\
México & 3 & 1 & 1 & 2 & 2 \\
Nicaragua & $14+$ & $15+$ & N/A & 20 & $15+$ \\
Panama & 5 & 8 & N/A & 4 & 9 \\
Paraguay & 12 & 14 & N/A & 11 & 10 \\
Peru & 1 & 7 & 7 & 7 & 8 \\
Puerto Rico & $14+$ & $15+$ & N/A & $20+$ & 4 \\
Dominican Republic & 11 & 11 & N/A & 11 & 11 \\
Uruguay & 10 & 9 & N/A & 9 & 8 \\
Venezuela & 4 & 5 & 6 & 6 & 7 \\
\hline
\end{tabular}

$\overline{\text { Table IV }}$

Correlation among indicators (Kendall's tau-b)

\begin{tabular}{lllcl}
\hline & \multicolumn{1}{c}{ FDI } & Exports & Deregulation & $\begin{array}{c}\text { International } \\
\text { financial centre }\end{array}$ \\
\hline Exports & $0.615^{* * *}$ & & & \\
Deregulation & 0.293 & $0.781 * * *$ & & \\
International financial centre & $0.675 * * *$ & $0.798 * * *$ & $0.488 *$ & \\
Insurance premiums & $0.468 * * *$ & $0.831 * * *$ & $0.488 *$ & $0.707 * * *$
\end{tabular}

Notes: * Significant correlation at level 0.10 (unilateral); ** significant correlation at level 0.05 (bilateral); *** significant correlation at level 0.01 (bilateral)

\section{Table V}

Correlation between the first year of entry and the indicators of "customer following" and "market seeking" (Kendall's tau-b)

\begin{tabular}{|c|c|c|c|c|c|}
\hline & BS & BBV & $\mathrm{BCH}$ & BEX & MAPFRE \\
\hline \multicolumn{6}{|c|}{ "Customer following" correlation with: } \\
\hline FDI & $0.362 * *$ & $0.421 * *$ & $0.400 * *$ & $0.307^{*}$ & 0.123 \\
\hline Exports & $0.769 * * *$ & $0.341 *$ & 0.198 & $0.390 * *$ & $0.290 *$ \\
\hline Deregulation & $0.878 * * *$ & 0.154 & -0.231 & 0.217 & 0.350 \\
\hline \multicolumn{6}{|c|}{ "Market seeking" correlation with: } \\
\hline International financial centre & $0.452 * *$ & $0.343 * *$ & $0.444 * *$ & $0.448 * *$ & \\
\hline Insurance premiums & & & & & $0.271 *$ \\
\hline \multicolumn{6}{|c|}{ Correlation with first year of entry } \\
\hline \multicolumn{6}{|c|}{ BS } \\
\hline BBV & $0.517 * * *$ & & & & \\
\hline $\mathrm{BCH}$ & 0.093 & 0.245 & & & \\
\hline BEX & 0.049 & 0.155 & 0.211 & & \\
\hline MAPFRE & $0.286 *$ & -0.141 & 0.059 & $0.259 *$ & \\
\hline
\end{tabular}

Notes: * Significant correlation at level 0.10 (unilateral); ** significant correlation at level 0.05 (unilateral); $* * *$ significant correlation at level 0.01 (unilateral) 
María José Álavarez Gil, Clara Cardone Riportella, Nora Lado Cousté and Margarita Samartín Sáenz Financial service firms' entry-mode choice and cultural diversity: Spanish companies in following aspects, but the other banks (BBV, $\mathrm{BCH}$ and $\mathrm{BEX}$ ) are not only "customer followers", but also "market seekers". It seems as if Banco de Santander has acted as the leader of the internationalisation process, and the other entities had followed it, directly or indirectly. As Hellman (1994) noted:

This game of tit for tat as Engwäll and Wallenstäl call it essentially means that the firms have reacted more strongly to the actions of their competitors than to any other changes in their environment.

With regards to the insurance company, it seems as if it has its own internationalisation pattern, and so there is no conclusive evidence for MAPFRE.

\section{Conclusions and extensions}

Our evidence corroborates that in addition to the distinction between manufacturing and service firms, the importance of factor locations could differ according to the country of the investor. Nationality differences stem from myriad cultural and economic influences translated into differences in firm behaviour regarding location choice. Authors such as Chernotsky (1983), Schollhammer (1974), Tong (1979), have found that different nationalities consider location factors differently. This is supported by Friedman et al. (1992), who found that the decision factors for Japanese and Europe MNCs were different.

As well as nationality considerations, Gronroos (1999) mentions "nationalism"; openness in the population to FDI (de Ruyter et al., 1998, demonstrated that "at least in Europe, young and more educated people, were less reluctant to accept foreign services") and governments' attitude towards it, as additional factors to be considered before entering a foreign market.

Therefore from a management (strategy and marketing) point of view, these should be the fundamental aspects to consider, in the first place. In this sense, it can be observed that both the Spanish banks and insurance company have followed entry strategies, that consisted in the acquisition or merger of local banks.

Our research findings expand earlier empirical studies that focused on internationalisation patterns of service companies by integrating deregulation considerations. In one of the cases considered in this study, we find there is a positive and significant correlation between the deregulation aspect and the internationalisation process.
We would like to point out that this finding was made possible by our use of a broader conceptualisation of the customer following construct that includes the above mentioned deregulation aspects.

One of the unique aspects of this research is that it has focused upon the process of internationalisation by Spanish financial services companies in Latin America, whereas virtually all previous research has examined the globalisation processes followed by other countries' enterprises in other destinies. Besides, such firms belonged to countries with a long cultural distance and different language and operated in other services activities. Hence, it is not surprising that the results that we report here show some divergences from other service studies. As a matter of fact, the results of the study of the internationalisation of the five Spanish financial service companies indicate that all entities (banks and insurer) seem to be influenced at the same time by "market seeking" and "customer following" aspects. In just one of them, "customer following" considerations have influenced the internationalisation process more. There are possible explanations for these results:

- in the case of BEX, it is a public bank, whose policy might differ from the one that guides private sector companies; and

- the host countries chosen by BBV, BCH and MAPFRE are neither a result of market seeking nor customer following considerations.

In these cases their strategies might have been influenced by the leader's initiatives, BS, or by the opportunity to buy a local company. These results provide evidence of the non-applicability of previous research findings (such as the ones obtained for Sweden and Finland) to explain the Spanish case.

Anyhow, the conclusions of this research should be interpreted taking into account the limitation in the availability of the data and the fact that the study has been limited to the Latin American market.

In closing, the empirical findings presented in this article provide relevant insights regarding the non-generalisation of previous Finnish and Swedish studies to the Spanish case. In this sense, it could be interesting to extend the internationalisation study of all European banks and insurance companies to the whole world. Preliminary results in this line of research can be found in the study carried out by Alvarez et al. (2000) which compares modes of entry for Spanish and Finnish banks in global markets. Their paper 
María José Álavarez Gil, Clara Cardone Riportella, Nora Lado Cousté and Margarita Samartín Sáenz Financial service firms' entry-mode choice and cultural diversity: Spanish companies in confirms, at least partially, the results obtained in our work.

Another area in need of further research relates to the success and profitability of the different international processes, which would in turn provide a more useful managerial contribution, too.

\section{Notes}

1 Service sector enterprises made up 61 per cent and 45 per cent of GNP in industrialised and emerging markets respectively. Such growth, may be explained, to a great extent, as a result of eliminating barriers to entry in the internationalisation of services proposed in the Uruguay Ronda (former GATT, 1993).

2 For example, Johanson and Wiedersheim-Paul (1975), Johanson and Vahlne (1977; 1990), Luostarinen (1979), Welch and Luostarinen (1988), Luostarinen and Welch (1990), Valhne and Nordstrom (1988) inter alia. According to their theories of internationalisation, which consider several stages of evolution, companies increase their presence in foreign markets gradually in terms of operational models, diversity of modes and range of markets penetrated. Researchers like these, from the Scandinavian "Uppsala School", emphasise an evolutionary pattern of international activity, during which organisational learning takes place, although it is difficult to generalise (Sullivan and Bauerschmidt, 1990).

3 Klassen and Whybark (1994) have pointed out that almost every article on the management of international operations has a discussion of the language and cultural elements that affect the activities. A discussion of these factors and how they might be managed can be found in Gladwin and Walter (1980).

4 A good discussion of the issues of managing people involved in international operations is found in Taylor (1991). Bartlett and Ghoshal (1992) describe a number of organizational and general management concerns that are difficult to manage. Technical factors are also potential issues in managing international operations, while a discussion of some of the monetary considerations is presented by Davis (1989). Goldhar (1989) has discussed some of the technology issues and Davis (1989) has concentrated on international logistics concern.

5 In the context of the GATT agreements now the WTO commitments regarding deregulation of banking and insurance services were organised around 11 topics. Out of the 63 countries that agreed to those commitments, ten were from Latin America.

6 This means that banking concentration has increased in Spain. Market share of the five biggest institutions in Spain Banco de
Santander, Banco Bilbao Vizcaya, Argentaria (formerly BEX), and Banco Popular has increased from 33 per cent in 1987 to 50 per cent in 1996.

7 Banco Central Hispano and Banco Santander merged in January 1999. Similarly, BBV and Argentaria merged in October 1999. After the mergers, the two new institutions accounted for nearly 20 per cent and 17 per cent of the market share respectively.

8 A detailed description of the entry years and percentages of the partial, or total acquisitions, for each of the three banks considered in this study, can be seen in Cardone and Cazorla-Papis (2001).

9 This indicator replaces the one defined in Hellman (1994), which is an indicator of cultural distance. In this work, the cultural aspect is not significant, given the closeness with nearly all countries, except Brazil, wherein Portuguese is spoken.

10 In order to see the entry years for the banks an insurance company analysed in this work, see note 9 and Table II.

\section{References}

Aliber, R.Z. (1984), "International banking: a survey", Journal of Money, Credit and Banking, November, pp. 661-78.

Alvarez $\mathrm{M}^{\mathrm{a}}$ J., Cardone, C., Lado, N. and Sasi, V. (2000), Going International: Are Financial Service Companies Following Manufacturing Firms: The Case of Finnish and Spanish Banks and Insurance Companies, CIBR WP Z-8; Centre for International Business Research, Helsinki School of Economics and Business Administration, Helsinki.

Andersen, O. (1993), "On the internationalisation process of firms: a critical snalysis”, Journal of International Business Studies, Vol. 24 No. 2, pp. 209-31.

Bartlett, C. and Ghoshal, S. (Eds) (1992), Transnational Management, Irwin, Homewood, IL.

Brush, T.H., Maritan, C.A. and Karnani, A. (1999), "The plant location decision in multinational manufacturing firms: an empirical analysis of international business and manufacturing strategy perspectives", Production and Operations Management, Vol. 8 No. 2, pp. 109-31.

Buckley, P.J., Pass, C.L. and Prescott, K. (1992), "The internationalization of service firms: a comparison with the manufacturing sector", Scandinavian International Business Review, Vol. 1 No. 1, pp. 39-56.

Campbell, A.J. and Verbeke, A. (1994), "The globalisation of service multinationals", Long Range Planning, No. 27/2, pp. 95-102.

Cardone, C. and Cazorla-Papis, L. (2001), "The internationalization process of Spanish banks in Latin America: a tale in two times", The 
María José Álavarez Gil, Clara Cardone Riportella, Nora Lado Cousté and Margarita Samartín Sáenz Financial service firms' entry-mode choice and cultural diversity: Spanish companies in
International Journal of Bank Marketing, February, Vol. 19 No. 2-3, pp. 53-67.

Chernotsky, H.I. (1983), "Selecting US sites: a case study of German and Japanese firms", Management International Review, No. 23, pp. 45-55.

Cho, K. (1986), "Determinants of international banks", Management International Review, Vol. 26, pp. 10-23.

Davis, E.W. (1989), "The money game: new pastime for Japanese manufacturers", in Ferdows, K. (Ed.), Managing International Manufacturing, North-Holland, Amsterdam.

de Ruyter, K., Van Birgelen, M. and Wetzels, M. (1998), "Consumer ethnocentrism in international services marketing”, International Business Review, Vol. 7, pp. 185-202.

Dunning, J.H. (1989), "Multinational enterprise and journal of the growth of service: some conceptual and theoretical issues", The Services Industrial Journal, No. 9, pp. 5-3.

Dunning, J.H. and McQueen, M. (1981), Transnational Corporations in the International Tourism, No. ST/CTC/18, UNCTC, New York, NY.

Engwall, L. and Wallenstäl, M. (1988), “Tit for tat in small steps: the internationalization of Swedish banks", Scandinavian Journal of Management, No. 4, pp. 147-55.

Erramilli, M.K. (1990), "Entry mode choice in service industries”, International Marketing Review, Vol. 7 No. 5, pp. 50-62.

Erramilli, M.K. (1991), "The experience factor in foreign market entry behaviour of service firms”, Journal of International Business Studies, Vol. 22 No. 3, pp. 479-501.

Erramilli, M.K. (1992), "Influence of some external and internal environmental factors on foreign market entry modes choice in service firms", Journal of Business Research, No. 25, pp. 263-76.

Erramilli, M.K. and Rao, C. (1990), "Choice of foreign market entry modes by services firms: role of market knowledge", Management International Review, Vol. 3 No. 3, pp. 135-50.

Erramilli, K. and Rao, C. (1993), “Service firms' international entry-mode choice: a modified transaction-cost analysis approach", Journal of Marketing, Vol. 57 No. 7, pp. 19-38.

Friedman, J., Gerlowski, D.A. and Silberman, J. (1992), "What attracts foreign multinational corporations? Evidence from branch plant location in the United States", Journal of Regional Sciences, Vol. 32 No. 4, pp. 403-18.

Giddy, I.H. (1986), "The theory and industrial organisation of international banking" in Gray, H.P. (Ed.), Research in International Business and Finance, JAI Press, Greenwich, CT, No. 3, pp. 195-243.
Gladwin, T.N. and Walter, I. (1980), "How multinationals can manage social and political forces", Journal of Business Strategy, Summer, Vol. 1, pp. 54-68.

Goldhar, J.D. (1989), "Implications of CIM for international manufacturing”, in Ferdows, K. (Ed.), Managing International Manufacturing, North-Holland, Amsterdam, pp. 239-58.

Gray, J.M. and Gray, H.P. (1981), “The multinational bank: a financial MNC", Journal of Banking and Finance, Vol. 5, pp. 3-63.

Grönroos, C. (1999), "Internationalization strategies for services", Journal of Services Marketing, Vol. 13 No. 4/5, pp. 290-7.

Grubel, H.G. (1977), "A theory of multinational banking”, Banca Nazionale del Lavoro Quertely Review, December.

Heinkel, R.L. and Levi, M.D. (1992), “The structure of international banking”, Journal of International Money and Finance, No. 11, pp. 251-72.

Hellman, P. (1994), "The internationalization of Finnish financial service companies”, International Business Review, Vol. 5 No. 2, pp. 191-208.

Johanson, J. and Mattson, L.G. (1988), "Internationalisation in industrial systems a network approach"; in Hood, H. and Vahlne, J.E. (Eds), Strategies in Global Competition, Croom Helm, Beckenham.

Johanson, J. and Vahlne, J.E. (1977), “The internationalization process of a firm. A model of knowledge, development and increasing foreign market commitments", Journal of International Business, Vol. 8 No. 1, pp. 23-32.

Johanson, J. and Vahlne, J.E. (1990), “The mechanism of internationalization", International Marketing Review, Vol. 7 No. 4, pp. 11-24.

Klassen, R.D. and Whybark, D.C. (1994), "Barriers to the management of international operations", Journal of Operations Management, No. 11, pp. 385-96.

Li, J. and Guisinger, S. (1992), "The globalization of service multinationals in the Triad regions: Japan, Western Europe and North America”, Journal of International Business Studies, Vol. 23 No. 4, pp. 675-96.

Lovelock, C.H. and Yip, G.S. (1996), "Developing global strategies for services business”, California Management Review, Vol. 38 No. 2, pp. 64-86.

Luostarinen, R. (1979), "Internationalization of the firm. An empirical study of the internationalization of firms with small and open domestic markets with special emphasis on lateral rigidity as a behavioral characteristic in strategic decision making", 
María José Álavarez Gil, Clara Cardone Riportella, Nora Lado Cousté and Margarita Samartín Sáenz Financial service firms' entry-mode choice and cultural diversity: Spanish companies in
Acta Academiae Oeconomiae Helsingiensis, Helsinki, Series A, p. 30.

MAPFRE (1997), Annual Reports.

Marjhgard, A. and Sharma, D.D. (1998), "Client-following and market-seeking strategies in the internationalization of service firms", Journal of Business-toBusiness Marketing, Vol. 4 No. 3, pp. 1-41.

Mathe, H. and Perras, C. (1994), "Successful global strategies for service companies”, Long Range Planning, Vol. 27 No. 1, pp. 36-49.

Nigh, D., Cho, K.R. and Krishnan, S. (1986), "The role of localisation related factors in US banking involvement abroad", Journal of International Business Studies, Vol. 17 No. 3, pp. 59-72.

O’Farrell, P.N., Wood, P.A. and Zheng, J. (1996), "Internationalisation of business service firms: an interregional analysis”, Regional Studies, Vol. 30 No. 2, pp. 101-18.

O'Farrell, P.N., Wood, P.A. and Zheng, J. (1998), "Internationalisation by business service SMEs: an inter-industry analysis", International Small Business Journal, Vol. 16 No. 2, pp. 13-33.

Sarathy, R. (1994a), "Entry strategies in the global expansion of service industries", in Bienmans, W.G. and Ghauri, P.N. (Eds), Proceedings of the 10th IMP Conference: Meeting the Challenges of New Frontiers, Groningen, pp. 307-26.

Sarathy, R. (1994b), "Global strategy in service industries”, Long Range Planning, Vol. 27, No. 6, pp. 115-24.

Schollhammer, H. (1974), Locational Strategies of Multinational Firms, Pepperdine University, Los Angeles, CA.

Sullivan, D. and Bauerschmidt, A. (1990), "Incremental internationalisation: a test of Johanson and Valhne's thesis”, Management International Review, Vol. 30 No. 1, pp. 19-30.

Taylor, W. (1991), "The logic of global business: an interview with ABB's Percy Barnevik", Harvard Business Review, Vol. 69, March/ April, pp. 91-105.

Terpstra, V. and Yu, C.M. (1988), "Determinants of foreign investment of US advertising agencies”, Journal of International Business, Vol. 19 No. 1, pp. 33-46.

Tong, H-M. (1979), Plant Location Decisions of Foreign Manufacturers, University Microfilms International Press, Ann Arbor, MI.

Valhne, J.E. and Nordstrom, K. (1988), "Choice of market channel in a strategic perspective", in Hood, N. and Vahlne, J.E. (Eds), Strategies in Global Competition: Selected Papers from the Prince Bertil Symposium, Croom Helm, New York, NY.

Wiedersheim-Paul, F., Olson, M.C. and Welch, L.S. (1978), "Pre-export activity: the first step in internationalisation", Journal of
International Business Studies, Spring/

Summer, pp. 83-91.

Williams, B. (1997), "Positive theories of multinational banking: eclectic theory versus internalisation theory", Journal of Economics Survey, Vol. 11 No. 1, pp. 71-100.

Winsted, K.F and Paterson, P.G. (1998), "Internationalization of services: the service exporting decision”, Journal of Services Marketing, Vol. 12 No. 4, pp. 294-311.

World Investment Report (1996), cited in "Inversiones españolas directas en América Latina en los años 90", in Ruesga, S. and Bichara, J. (Eds), Boletín ICE Económico (1998).

\section{Further reading}

Bank for International Settlements (1998), Monetary and Economy Department International Financial Statistics, November.

Boddewyn, J., Halbrich, M. and Perry, A. (1986), "Service multinationals: conceptualisation, measurement and theory", Journal of International Business Studies, No. 4, pp. 41-58.

Casson, M. (1990), "Evolution of multinational banks: a theoretical perspective", in Jones, G. (Ed.), Banks as Multinationals, Routledge, London.

Dunning, J. (1988), "The eclectic paradigm of international production: a restatement and some possible extensions", International Business Studies, No. 19, pp. 1-32.

Enderwick, P. (1989), "Some economics of service-sector multinational enterprise”, in Enderwick, P. (Ed.), Multinational Service Firms, Routledge, London.

Goldberg, L.G. and Johnson, D. (1990), “The determinants of US banking activity abroad", Journal of International Money and Finance, Vol. 9, pp. 123-37.

Johanson, J. and Wierdersheim-Paul, F. (1975), "The internationalization of the firm. Four Swedish cases”, Journal of Management Studies, Vol. 12 No. 3, pp. 11-24.

Kindleberger, C.P. (1985), "Multinational ownership of shipping activities”, World Economy, September, Vol. 8, pp. 249-65.

Li, J. (1994), "Experience effects and international expansion: strategies of services MNC's in the Asia-Pacific region", Management International Review, Vol. 34 No. 3, pp. 217-34.

Luostarinen, R. and Welch, L.S. (1990), International Business Operations, Helsinki School of Economics, Helsinki.

Mahajan, A., Ragan, A. and Zardkoohi, A. (1996), "Cost structures in multinational and domestic banking", Journal of Banking and Finance, No. 20, pp. 283-306.

Salomon Smith Barney (1997), Bank Reference Guides of Argentina, Brazil, Chile, Colombia, Mexico, Peru and Venezuela, December. 
María José Álavarez Gil, Clara Cardone Riportella,

Nora Lado Cousté and

Margarita Samartín Sáenz

Financial service firms'

entry-mode choice and

cultural diversity: Spanish

companies in
Salomon Smith Barney (1998), Latin American Equity Research: Latin America-Banks Latin American Bank Annual, May.

Ulgado, F.M. (1996), "Location characteristics of manufacturing investments in the US: a comparison of American and foreign-based firms”, Management International Review, No. 1, pp. 7-26.

Weinstein, A.K. (1977), "Foreign investments by services firms: the case of multinational advertising agencies", Journal of International Business Studies, Spring-Summer, pp. 83-91.

Welch, I.S. (1990), "Internationalization by Australian franchisors", Asia Pacific Journal of Management, Vol. 7 No. 2, pp. 101-21.

Welch, L.S. and Luostarinen, R. (1988), "Internationalization: evolution of a concept", Journal of General Management, Vol. 3 No. 2, pp. 34-55. 